\author{
Anna Kolodziej \\ Katedra Nauk Spolecznych, \\ Wydziat Studiów Spolecznych, \\ Wyższa Szkoła Bezpieczeństwa w Poznaniu
}

\title{
Problematyka patriotyzmu w wychowaniu harcerskim w Związku Harcerstwa Rzeczypospolitej (ZHR)
}

\author{
Nie będzie spokoju na świecie, póki rasa ludzka nie wyzbędzie się patriotyzmu. \\ George Bernard Shaw (1856-1950) \\ Patriotyzm to żywe poczucie zbiorowej odpowiedzialności. \\ Richard Aldington (1892-1962) \\ Główną cnota [dla mojego pokolenia] nie była już miłość do swego kraju, ale współczucie dla bliźnich. \\ Noel Annan (1916-2000) \\ Władysław Kopaliński, Słownik wydarzeń, pojęć i legend XX wieku, \\ Warszawa 1999, s. 306-307.
}

\begin{abstract}
Issues of patriotism in scouting education in the ZHR Polish Scouting and Guiding Association.

The historical education of youth has played an important role in patriotic education. The results of academic research into the patriotism of Polish youth shows the growing need of patriotic education in the context of situating patriotism as an independent category, an element of the axiological system, the awareness of Polish youth. The analysis of contemporary Polish reality indicates new challenges in patriotic education.

With the ZHR we are dealing with a specific vision of our history, as well as a specific version of present times and a specific cultural code.

Scouting is considered an organization that has become an inherent part of Polish tradition and culture, and the ideal of being raised in the scouting tradition has been established in the consciousness of a number of generations of Poles.

It is a consequence of our national culture and tradition. Scouting has been used as a tool for developing an independent attitude amongst patriotic youths. It also became an essential part of the struggle for independence.

Scouting as a system of education has been subject to change and ongoing development in changing socio-political and economic conditions. This process has continued in the contemporary, postmodern and post-industrial society. Patriotic education in scouting is an element of scouting methodology based on Scouting Law and the Scouting Oath.
\end{abstract}

Keywords: scouting, patriotism, patriotic education 
Rozważania dotyczące problemu teoretyczno-metodologicznego podejścia do patriotyzmu we współczesnym społeczeństwie polskim wiążą się z warunkami funkcjonowania nauk o wychowaniu w Polsce w społeczeństwie pluralistycznym i otwartym, które jest w stanie zmiany systemowej w Polsce po roku 1989. W naukach o wychowaniu zmiana systemowa spowodowała otwarcie się na nowe, nieznane dotąd podstawowe paradygmaty ${ }^{1}$ oraz podjęcie poszukiwań w środowisku naukowym, dyskursie nad wychowaniem możliwości stworzenia metateorii wychowania, czyli metapedagogiki [...], poznania, wyjaśniania czy porównywania różnych teorii wychowania ${ }^{2}$. Doniosłość tego problemu potwierdza między innymi VII Ogólnopolski Zjazd Pedagogiczny w Toruniu we wrześniu 2010 r., na którym podjęto sprawę stanu pedagogiki i realiów jej rozwoju w ogóle, w świecie współczesnym ${ }^{3}$.

Słuszny wydaje się także pogląd konieczności prowadzenia analiz problematyki patriotyzmu we współczesnym społeczeństwie polskim, kwestii patriotyzmu w ruchach, organizacjach i stowarzyszeniach społecznych w kontekście nasilającego się procesu, który socjologowie określają mianem erozji myślenia $w$ kategoriach dobra wspólnego ${ }^{4}$. Nie sposób nie uwzględniać także, że na proces ten nakłada się poważna bariera, utrudniająca dokonanie kolejnego ,,skoku modernizacyjnego”, którą można okréślić nastepująco: sposoby radzenia sobie społeczeństwa polskiego z rzeczywistościa sa wciaż bardziej taktyczne niż strategiczne [...] Polacy wciąż raczej reagują na zadany im porzadek niż go aktywnie współtworza i zmieniają ${ }^{5}$.

Edukacja historyczna młodzieży ma od dawna określoną rolę w wychowaniu patriotycznym. Wyniki badań socjologicznych nad patriotyzmem polskiej młodzieży wskazują na rosnącą potrzebę wychowania patriotycznego w kontekście usytuowania patriotyzmu jako samodzielnej kategorii światopoglądowej, elementu systemu aksjologicznego, świadomości współczesnej młodzieży polskiej ${ }^{6}$. Analiza współczesnej polskiej rzeczywisto-

1 B. Śliwerski, Współczesne teorie i nurty wychowania, Kraków 2005, s. 9-11.

2 Ibidem, s. 11.

${ }^{3}$ B. Śliwerski, Wprowadzenie, w: Pedagogika, t. 4: Subdyscypliny i dziedziny wiedzy o edukacji, red. nauk. B. Śliwerski, Gdańsk 2010, s. X-XI. Autor zwraca uwagę na odsłanianie kolejnych pól badawczych poszukiwań w naukach o wychowaniu oraz dociekań dotyczących ich możliwych zastosowań w praktyce edukacyjnej (s. XI). Odwołuje się do poglądu wskazującego, że pedagogika musi odpowiadać na najważniejsze wyzwania społeczne swojego czasu. Z drugiej zaś strony musi wpisywać się w określony model nauki (naukowości, racjonalności); T. Hejnicka-Bezwińska, Kontekst pytania o „,koniec pedagogiki jako nauki”, „Edukacja. Studia. Badania. Innowacje” 2009 nr 4, s.13. Za: ibidem, s. XI. Sądzę, że jest to trafne sformułowanie odnoszące się niewątpliwie do problemu patriotyzmu, wychowania patriotycznego.

${ }^{4}$ R. Drozdowski, Postmodernizacyjna misja uniwersytetu, „Życie Uniwersyteckie” 2011 nr10(217), s. 19. Cytowany tekst jest wykładem inauguracyjnym wygłoszonym na inauguracji roku akademickiego 2011/2012 w Uniwersytecie im. Adama Mickiewicza w Poznaniu.

5 Ibidem.

${ }^{6}$ P. Ruszkowski, Patriotyzm $w$ hierarchii wartości młodziė̇y $w$ świetle badań empirycznych, w: Wizja polskiego patriotyzmu, Centralny Ośrodek Doskonalenia Nauczycieli, Warszawa 2008, s.47-50; B. Polak, Patriotyzm Polaków po przełomie 1989 r., ibidem, s. 21-27. B. Polak przytacza opinie autorki pracy Młodzież PRL, sformułowaną w 2006 r.: wśród roczników dojrzewających po przełomie 1989 roku widać wyraźna niechęć do pojęcia patriotyzmu, które ma przede wszystkim negatywne konotacje. Studenci i licealiści patriotyzm uważają za anachronizm i sferę związana z polityka, a polityki nie znosza. Co więcej, nie odróżniają nacjona- 
ści, proces transformacji systemowej w Polsce po 1989 r., będącej integralną częścią Unii Europejskiej, wskazują na nowe wyzwania w edukacji patriotycznej ${ }^{7}$.

W literaturze przedmiotu występują różne definicje pojęcia ,patriotyzm”.

W Nowej encyklopedii PWN patriotyzm zdefiniowano jako umiłowanie ojczyzny $\rightarrow$ zdolność poświecenia się dla niej, stawianie dobra swego kraju ponad partykularne interesy własne $i$ własnej klasy, profesji, partii itd.; $w$ niektórych sytuacjach hist[orycznych] także określenie orientacji polit[ycznej], [...] często, choć nie we wszystkich językach i ideologiach przeciwstawiany $\rightarrow$ nacjonalizmowi, jako tylko takie przywiazanie do ojczyzny i tylko taka solidarność z własnym $\rightarrow$ narodem, którym nie towarzyszy wrogość do innych narodów i chęć ich poniżenia, duma nar[odowa] zaś nie przeksztatca się $w$ megalomanię ${ }^{8}$. W encyklopedycznym opracowaniu Jan Pawet II. Encyklopedia nauczania społecznego czytamy: Patriotyzm - [...] postawa wobec ojczyzny, narodu, przejawiajaca się rzetelna praca, przedkładaniem nadrzędnych wartości niepodległości i suwerenności nad własne cele, gotowościa do ich obrony, nawet za cene życia; łaczy przywiąanie i miłość do ojczyzny, solidarność z własnym narodem [...] ${ }^{9}$. Patriotyzm [to] miłość do swojego kraju bądź gotowość do obrony jego interesów ${ }^{10}$. A także postawa wyrażajaca się $w$ wypetnianiu podst[awowych] konstytucyjnych obowiązów obywatelskich, takich jak: stużba wojsk[owa], i obrony ojczyzny, wierność dla kraju, troska o wspólne dobro i dbałość o stan środowiska naturalnego, przestrzeganie prawa, goto-

lizmu od patriotyzmu, ibidem, s. 21. Z badań przeprowadzonych wśród studentów różnych wydziałów Uniwersytetu Warszawskiego wynika, że patriotyzm znalazł się na 78 miejscu spośród 80 pojęć w odpowiedziach badanych na pytanie: jakie kategorie uważasz za bliskie dla środowiska studenckiego, jaka rolę odgrywaja w twoim życiu? Ibidem.

${ }^{7}$ H. Skorowski ks., Nowa edukacja patriotyczna, w: Wizja polskiego patriotyzmu, Warszawa 2008, s. 51-74. Autor rozważania o edukacji patriotycznej umiejscawia w kontekście patriotyzmu, który stanowi określone wyzwanie $\mathrm{w}$ warunkach tendencji do globalizacji i integracji, i w rozumieniu autora absolutyzowanie dążenia do globalizacji i integracji oznacza $w$ świecie dzisiejszym ujednolicenie, ujednostajnienie, jednoksztaltność. Ibidem, s. 52-53. Najogólniej celem nowej edukacji patriotycznej winno być ukształtowanie poczucia własnej tożsamości narodowej jako podstawy zaangażowania się w funkcjonowanie własnego środowiska i autentyczne otwarcie na inne społeczności i kultury. Ten ogólny cel rozkłada się na cele bardziej szczegółowe. [...] Ibidem, s. 54. Celem edukacji patriotycznej jest uksztaltowanie postaw patriotycznych. Edukacja patriotyczna nie stoi w sprzeczności z edukacja europejska. Można nawet powiedzieć, że edukacja patriotyczna rozumiana jako umiłowanie własnej ojczyzny jest w jakimś sensie edukacja europejska. Ibidem, s. 74. Mając na uwadze personalizm chrześcijański, uznany za podstawę wychowania harcerskiego w ZHR (w Podstawowych zasadach wychowania harcerskiego $w$ ZHR) warto zwrócić uwagę - w kontekście rozważań o wychowaniu patriotycznym - na publikację Jan Pawel II nauczycielem patriotyzmu, pr. zbior. pod red. ks. Adama Bałabucha, Świdnica 2008, a w szczególności na następujące teksty: bp I. Dec, Antropologiczne podstawy patriotyzmu $w$ nauczaniu Jana Pawła II, s. 57-69; ks. prof. dr hab. A. Zwoliński, Kultura fundamentem współczesnego patriotyzmu, s. 71-90; dr hab. A. Rynio, Integralne wychowanie osoby szansa rozwoju i przetrwania, s. 91-108; S. C. Michałowski, Pedagogiczny wymiar nauczania patriotycznego Jana Pawta II. Studium personalistyczne, s. $121-157$.

${ }^{8}$ Nowa encyklopedia PWN, Warszawa 1996, s. 801. Natomiast Encyklopedia socjologii, Warszawa 2000; Stownik spoleczny, praca zbior. pod red. B. Szlachty, Warszawa 2004; C. Kupisiewicz, M. Kupisiewicz, Stownik pedagogiczny, Warszawa 2009; W. Okoń, Słownik pedagogiczny, Warszawa 1981; Encyklopedia pedagogiczna XXI wieku, Warszawa 2005 nie zawierają definicji pojęcia patriotyzm.

9 Jan Pawet II. Encyklopedia nauczania społecznego, pod red. ks. prof. dr. hab. Andrzeja Zwolińskiego, Radom 2005, s. 353.

${ }^{10}$ P. Burgoński, Patriotyzm w Unii Europejskiej, Warszawa 2008, s. 405. 
wość do ponoszenia wszelkich ciężarów i świadczeń, w tym też płacenia podatków ${ }^{11}$. Patriotyzm w znaczeniu ogólnym [to] wszelkie umiłowanie $\rightarrow$ ojczyzny jako miejsca swojego pochodzenia i/lub zamieszkania; ojczyzna w tym sensie może być każda okolica lub region, do którego jednostka jest szczególnie przywiązana ${ }^{12}$.

Postawy patriotyczne kształtowane są u człowieka w procesie wychowania.

W pedagogice pojęcie „wychowanie” jest zdefiniowane z bardzo różnych perspektyw, stanowisk, czy teorii, które bliższe sa postrzeganiu go jako oddziaływania jednokierunkowego lub wzajemności wplywów ${ }^{13}$. [...] Ostatecznym wyjaśnieniem pojęcia „,wychowanie” pozostaje samodzielny wybór jakiejś koncepcji czy teorii w zależności od osobistych preferencji, źródeł lub uzasadnień. Żadna z istniejacych konwencji terminologicznych nie jest „błędna”, żadna nie jest też prawdziwa. Niemożliwe jest sformułowanie jednej, „ostatecznej” i kulturowo uniwersalnej definicji wychowania, nie jest ono bowiem stanem wyłącznie obiektywnym, który jest dany, lecz $w$ dużej mierze konstrukcją społeczna. Każda z definicji $w$ jakimś stopniu opisuje wychowanie jako zjawisko, które nie jest ontologicznie monolityczne, ale jest różnorodne, skomplikowane, czasami wewnętrznie sprzeczne, dynamiczne i otwarte $w$ trakcie stawania się. [...] To, co możemy określić jako wychowanie, nigdy nim nie będzie, gdyż możemy tylko orzekać o tym, co jest, a wychowanie jako zjawisko intersubiektywne, w sensie ścistym, nie jest, lecz się staje $e^{14}$.

W literaturze przedmiotu występują różne określenia wychowania patriotycznego, nazywanego także wychowaniem obywatelskim, które stanowi znaczącą pedagogicznie dziedzinę wychowania. Przez pojęcie „wychowanie patriotyczne” najogólniej rozumie się wdrażanie lub przyuczanie do umiłowania własnej ojczyzny i narodu łacznie z gotowościa do wyrzeczeń $i$ ofiar dla nich ${ }^{15}$. Celem wychowania patriotycznego jest przygoto-

11 Stownik encyklopedyczny. Edukacja obywatelska, Wrocław 1999, s. 288.

12 Wielka encyklopedia PWN, Warszawa 2004, s. 380.

13 B. Śliwerski, Teorie wychowania, w: Pedagogika, t. 4: Subdyscypliny i dziedziny wiedzy o edukacji, red. nauk. B. Śliwerski, Gdańsk 2010, s. 210. Zob. definicje wychowania w kontekście cytowanej tezy przedstawione przez autora zamieszczone w tekście s. 230-231. Zob. także szerokie przedstawienie etymologii pojęcia wychowanie, różnorodności definicji wychowania, istoty wychowania, spolecznego kontekstu oddziatywań wychowawczych, dialektycznej jedności wychowania i samowychowania, problematyki wychowania w toku ontogenezy, granic, krytyki i antynomii wychowania w: B. Śliwerski, Wychowanie. Pojęcie - znaczenia - dylematy, w: Wychowanie. Pojęcia-Procesy - Konteksty, t. I, red. nauk. M. Dudzikowa, M. Czerepaniak-Walczak, Gdańsk 2007, s. 55-76. Śliwerski swoje obszerne rozważania konkluduje następująco: Każda z podejmowanych przez naukowców prób usystematyzowania wiedzy na temat istoty wychowania kończy się niepowodzeniem. Zob. także K. Skarżyńska, Rodzaje patriotyzmu. Czy i jak osobiste doświadczenia oraz wychowanie różnicuja postawy narodowe?, w: Wychowanie. Pojęcia-Procesy-Konteksty, t. IV, red. nauk. M. Dudzikowa, M. Czerepaniak-Walczak, Gdańsk 2008, s. 55-72.

${ }^{14}$ Ibidem, s. 230-237. Podobne stanowisko przedstawia Z. Melosik, który pisze: Żadna jednak teoria wychowania nie może już być rozpatrywana jako zdystansowana, obiektywna forma oglądu rzeczywistości wychowawczej, gdyż każda z nich odwołuje się do określonych wartości, idei czy doktryn. Sa one, podobnie jak świadomość ich twórców, integralna częścia rzeczywistości, która opisuja, wyjaśniają i pragna zmieniać. (Z. Melosik, Postmodernistyczne kontrowersje wokót edukacji, Toruń, Poznań, Edytor 1995, s.20. Za: B. Śliwerski, Teorie wychowania, w: Pedagogika, t. 4: Subdyscypliny i dziedziny wiedzy o edukacji, red. nauk. B. Śliwerski, Gdańsk 2010, s. 230).

15 M. Łobocki, Teoria wychowania w zarysie, Kraków 2009, s. 277. Podobne ujęcie definicyjne patriotyzmu w: Stownik pedagogiczny, C. Kupisiewicz, M. Kupisiewicz,Warszawa 2009, s. 193; W. Okoń Stownik 
wanie wychowanków do służby własnemu narodowi i państwu, kształtowanie przywiązania i miłości do kraju ojczystego, jego przeszłości i teraźniejszości, rozwijanie gotowości do obrony własnego państwa działania na rzecz jego bezpieczeństwa. W wychowaniu patriotycznym dużą wagę przywiązuje się do edukacji w zakresie wiedzy o własnym narodzie i państwie oraz kształtowaniu poczucia solidarności z własnym narodem, emocjonalnej więzi międzypokoleniowej oraz działaniu na rzecz dobra wspólne$\mathrm{go}^{16}$. Stanisław Ossowski podkreślał wieloznaczności, w których przejawiają się skomplikowane postawy wobec ojczyzny $i$ narodu ${ }^{17}$.

Można przyjąć, że władze państwowe, instytucje państwowe i społeczne, ruchy, organizacje i stowarzyszenia społeczne przywiązywały dużą wagę do wychowania patriotycznego oraz nadają temu wychowaniu większe lub mniejsze znaczenie współcześnie. Jednak, jak zauważa historyk Marcin Kula, Nie w każdym kraju i nie zawsze kładziono $i$ kładzie się nacisk na wychowanie patriotyczne. Silni siła spokoju chyba nie potrzebuja specyficznego wychowania patriotycznego, gdyż po prostu sa patriotami. Aprobowane poczucie przynależności do własnej grupy jest wszak naturalna postawa człowieka ${ }^{18}$. Na ogół nacisk na wychowanie patriotyczne występuje, gdy narody, państwa, grupy społeczne, indywidualni ludzie są w warunkach niepewności samopoczucia narodowego, przeżywają rozliczne kłopoty. Przede wszystkim nacisk na wychowanie patriotyczne kładzie się w ruchach niepodległościowych, odrodzenia i wyzwolenia narodowego, państwach młodych i słabych, w których poszukuje się sposobów jednoczenia obywateli i kształtowania dumy obywatelskiej. Zjawisko nacisku na wychowanie patriotyczne ma miejsce także w krajach imigranckich zagrożonych lub mających poczucie zagrożenia o różnym charakterze ruchach nacjonalistycznych w sytuacjach potrzeby skompensowania braku własnego działania i odrzucenia oskarżenia o obcość. W wymienionych sytuacjach intensywne wychowanie patriotyczne jako świadome zadanie nie należy rozpatrywać w każdym przypadku negatywnie. Można rozpatrywać objawowo, albowiem nawet w ramach

pedagogiczny, Warszawa 1981, s. 349-350. Mając na uwadze wieloznaczność pojęcia patriotyzm oraz różnorodność jego definiowania, warto wskazać, że w naukach humanistycznych występują definicje patriotyzmu, których celem jest próba wywołania u odbiorcy definicji postawy niechętnej lub skłonienia odbiorcy do odrzucenia danej definicji. Przykładem może być następująca definicja: „Patriotyzm” - to postawa, która stawia naród ponad ludzkość, ponad ideały prawdy i sprawiedliwości, a nie petne miłości zainteresowanie sprawami własnego narodu, które stuży jego pomyślności duchowej i materialnej, nigdy zaś przemocy nad innymi narodami. (E. Fromm, Der heutige Mensch und seine Zukunft, Frankfurt/M, 1960, s. 55. Za: T. Pawłowski, Pojęcia i metody wspótczesnej humanistyki, Wrocław-Warszawa-Kraków-Gdańsk 1977, s. 144.).

${ }^{16}$ Ibidem, s.277-278. Zob. także cytowana przez M. Łobockiego literatura przedmiotu.

17 S. Ossowski, Analiza socjologiczna pojęcia ojczyzny, w: S. Ossowski, O ojczyźnie i narodzie, Warszawa 1984, s. 26. Publikacja, do której wstęp napisał Jerzy Szacki zawiera teksty przedrukowane z: S. Ossowski, Dzieła, t. III, Warszawa 1967. Teksty te zostały ogłoszone - jak pisze J. Szacki - w ciągu pięciu powojennych lat. W kontekście problematyki patriotyzmu warto mieć na uwadze, że naród w koncepcji S. Ossowskiego nie jest spoleczeństwem kultury narodowej [lecz] społeczeństwem ideologii narodowej. J. Szacki, Wstęp, w: S. Ossowski, O ojczyźnie $i$ narodzie, s. 11. Ossowski twierdzi, że patriotyzm ma dwojaki wymiar. Pierwszą postać patriotyzmu nazywa prywatna ojczyzna. Postać drugą - ojczyzna ideologiczną. Przy analizie postaw patriotycznych według S. Ossowskiego można rozróżniać więź ideologiczną $i$ więź nawykową. Ibidem, s. 26, 28.

${ }_{18}$ M. Kula, Nieznośny ciężar kompleksów, Uwagi o wychowaniu patriotycznym z przeszłościa $w$ tle, w: Wychowanie. Pojęcia - Procesy - Konteksty, t. IV, red. nauk. M. Dudzikowa, M. Czerepaniak-Walczak, Gdańsk 2008, s. 29. 
nacjonalizmu mogą występować bardzo różne sytuacje, stany rzeczy. Na przykład w państwie odrodzonym, w którym nacisk na wychowanie patriotyczne może być zrozumiały w odróżnieniu od państwa prowadzącego hegemonistyczną politykę zagraniczną, mającą na celu osiąganie, umacnianie dominującej pozycji w społeczności międzynarodowej W sposób sprzeczny z zasadami stosunków międzynarodowych. W wychowaniu patriotycznym istotnym elementem bywa historia, aczkolwiek nie jest ona konieczna. Jednak wiedza o przeszłości jest wiedzą pozwalającą lepiej funkcjonować w społeczeństwie. Historia odgrywa ważną rolę w kształtowaniu więzi społecznej i działaniu na rzecz wspólnoty. Poczucie wspólnych korzeni pozwala na osiąganie i wzmacnianie poczucia jedności grupowej, narodowej, społecznej. Może być także czynnikiem i instrumentem dowartościowywania społeczności, jej narzędziem kompensacji lub też szukaniem swoistego psychologicznego schronienia ${ }^{19}$. Generalnie jednak Człowiek dziedziczy przeszłość. Spadek to czasem przyjemny a czasem kłopotliwy, ale taki którego nie można nie przyjać, [aczkolwiek] W wielu wypadkach zaszłości ograniczaja nasza swobodę działania ${ }^{20}$.

Niewątpliwie wizja historii jest częścia kultury $i$ kodu kulturowego ${ }^{21}$.

Uwaga powyższa odnosi się do edukacji historycznej w ogóle, w szczególności w obszarze dokonywania określonych wyborów procesów historycznych, zdarzeń historycznych, faktów historycznych, postaci historycznych będących przedmiotem i treścią edukacji historycznej, wychowania patriotyczno-obywatelskiego we wszelkich instytucjonalnych jego formach, w tym również w ramach ruchów społecznych, organizacji społecznych, stowarzyszeń społecznych.

Z określoną wizją naszej historii, jak również określoną wersją współczesności oraz swoistym kodem kulturowym mamy do czynienia w ZHR. Harcerstwo uważane jest za organizację na trwale wpisaną w polską tradycję i kulturę, a model skautowego wycho-

19 Ibidem, s. 29-32. M. Kula wskazuje, że Warto zdawać sobie wszakże sprawę, że historia nie jest niezbędna jako , smar” patriotyzmu (ibidem, s. 32). Podkreśla również, że w wielu państwach zwraca się uwage na coś, co można by nazwać wychowaniem obywatelskim - czyli na nauke o państwie i jego instytucjach. Oczywiście nauka o symbolach oraz instytucjach państwa może być bliska krzewieniu postaw patriotycznych, ale nie musi być jednoznacznie powiąana z działaniem $w$ tym kierunku (ibidem, s. 29).

${ }^{20}$ M. Kula, Przeszłość: spadek nie do odrzucenia, Poznań 2001, s. 5, 10. Autor uważa, że Dziedziczenie przeszłości przechodzi przez filtr mechanizmu, w którym zawsze mamy do czynienia współdziałaniem podłoża historycznego, nakładających się późniejszych zaszłości, oraz sytuacji dzisiejszej (s. 64). W kontekście rozważań o historycznych uwarunkowaniach sporów o tożsamość harcerstwa polskiego, pojmowania patriotyzmu, wychowania patriotycznego w harcerstwie warto zwrócić uwagę na pogląd M. Kuli wyrażony w stwierdzeniu, że: Ograniczenia spowodowane przeszłościa [...] Raz powstałe nienawiści pomiędzy jednostkami, grupami [...] $w$ przemożnym stopniu determinuja dalszy bieg historii. [...] Szukanie odpowiedzi na pytanie o skutki zaszłości z jednej strony, a o genezę z drugiej jest jednym z podstawowych nurtów badań historycznych i jednym z głównych pól zawodowych sporów historyków [przy czym należy mieć na uwadze, że] metryka niejednego zjawiska jest dyskusyjna [...] tym trudniejsza do ustalenia, w im większym stopniu początek jest procesem, a nie wydarzeniem. Ibidem, s. 12-13, 31, 44-45, 64. M. Kula podkreśla również za historykiem Piotrem Wandyczem, że najpewniej spuściznę XIX w. stanowi w Polsce wiara w posłannictwo i cechy narodowe, kult martyrologii, często negatywna postawa wobec kompromisów, a także skłonność do konspirowania, którą też najpewniej tłumaczy się doświadczeniem historycznym. Ibidem, s. 31. P. Wandycz mówił o tym w referacie Rola powstań $w$ dziejach nowożytnych Polski wygłoszonym podczas otwarcia XV Powszechnego Zjazdu Historyków Polskich w Gdańsku 15 września 1994 r. Ibidem, s. 73.

${ }^{21}$ M. Kula, Historia jest częścia ludzi, „Sensus Historiae. Studia interdyscyplinarne” 2011 nr 2, s. 111. 
wania niewątpliwie utrwalił się w świadomości wielu pokoleń Polek i Polaków. Stanowi dorobek narodowej kultury i tradycji.

Model wychowania harcerskiego nie powstał jednorazowo. Był to proces towarzyszący sporom ideowym w polskim ruchu harcerskim, intelektualnym refleksjom, polemikom nad rolą i miejscem harcerstwa w społeczeństwie i państwie polskim.

Zasadnym jest postrzeganie ZHR-owskiej wizji historii, wersji współczesności, wychowania patriotyczno-obywatelskiego oraz metody harcerskiej w kontekście sporu historycznego o tożsamość harcerstwa polskiego, którego źródła sięgają genezy skautingu na ziemiach polskich pod zaborami, i który trwa nadal we współczesnym polskim harcerstwie. Warto w tym miejscu przytoczyć stwierdzenie historyka dziejów harcerstwa Wojciecha Hausnera, który wskazuje, że pojmowanie harcerstwa wyłącznie jako przygody w lesie, dobrej zabawy $i$ obozu lub szkoły przetrwania jest błędne. Harcerstwo, To wielki ruch społeczny, w którym bardzo ważny jest wymiar ideowy. I właśnie wokół tego wymiaru $w$ historii harcerstwa dochodziło do sporów. To klucz do zrozumienia wielu wydarzeń $w$ historii z harcerstwa ${ }^{22}$. Zróżnicowanie ideowe i podziały organizacyjne, które były istotne, należą do cech charakterystycznych polskiego ruchu harcerskiego. U jego początków był to między innymi spór pomiędzy nurtem etyczno-moralnym oraz niepodległościowym ${ }^{23}$. Przecież już w pierwszych latach istnienia skautingu polskiego, kształtowania się oblicza ideowego tego ruchu występowały dwa główne nurty myślenia. Był to nurt narodowo-chrześcijański oraz nurt narodowo-obywatelski ${ }^{24}$. W harcerstwie polskim podziały ideowe i organizacyjne były zjawiskiem stałym na wszystkich etapach historii skautingu i harcerstwa. W wydarzenia roku 1989 harcerstwo wkroczyło od dawna głęboko podzielone, co miało podstawowe przyczyny ideowe, a także byto wynikiem

${ }^{22}$ W stużbie Bogu, Ojczyźnie i bliźnim. O skautingu i harcerstwie z Wojciechem Hausnerem rozmawia Barbara Polak. ,, Biuletyn Instytutu Pamięci Narodowej”, 2010 nr 5-6 (114-115), s. 17. Zob. także uwagi na temat sporów ideowych w skautingu w pracy: W. Hausner, Krakowski skauting 1910-1914, Wydawnictwo „Czuwajmy”, Kraków 1994, s. 143-149. Jak twierdzi T. Strumiłło, Pomimo ogólnego zapału i karności, różne grupy mlodzieży, popierające ruch harcerski nie umiały się wznieść na stanowisko wyższej jedności, sprowadzającej ich odrębności do wspólnego mianownika. Zarówno odmienny sposób pojmowania skautingu, jak i odmienne zorientowanie polityczne, a nie rzadko poprostu ambicje organizacyjne podsycały odśrodkowe tendencje $i$ wytwarzały tarcia. Najogólniej biorąc, dwa prądy można było wyróżnić: spokojniejszy zmierzat do głębszego wychowawczego oddziaływania przez skauting na młodzież, gorętszy rwat się do "kucia broni”, kształcenia przede wszystkim przysztych żotnierzy. Pierwszy prąd reprezentowali głównie Elsowie, drugi - Zarzewiacy, ściślej - „Strzelcy”, Sokole czynniki usiłowały pośredniczyć i godzić te tendencje. (T. Strumiłł, Nasze dzieje. Geneza harcerstwa, „Harcerski Zeszyt Historyczny” Nr 3/2, s. 14, w: Historia harcerstwa, t. 1: Lata 1910-1921, Londyn 1975.)

${ }^{23}$ W. Hausner hm, Raport o stanie harcerstwa, w: Semper Fidelis, oprac. i wybór zdjęć Marek Różycki, Warszawa 1998, s. 41. Raport opracowano w związku z pielgrzymką delegacji ZHR do Watykanu w sierpniu 1996 r. Ocenę sytuacji w harcerstwie w dziedzinie ideowej do 1939 r., w okresie wojny i okupacji 1939-1945, w latach 1945-1980, którą W. Hausner określa jako ferment ideowy zawiera część Raportu zatytułowana Mit jedności harcerstwa, s. 41-44. Dalsze części Raportu traktują o harcerstwie niepokornym w latach osiemdziesiątych, micie rozłamu 1989 r., sporze o harcerstwo i próbie integracji ruchu harcerskiego w latach dziewięćdziesiątych, s. 44-48. Ostatnia część Raportu dotyczy usytuowania ZHR w ruchu harcerskim, s. 49. We wszystkich częściach Raportu W. Hausner podkreśla zjawiska ideowych sporów w harcerstwie.

${ }^{24}$ Zob. uwagi J. Kurzępy na temat charakteru związków harcerskich w perspektywie analizy porównawczej w artykule Rola organizacji harcerskich w budowaniu społeczeństwa obywatelskiego, „Rocznik Lubuski” 2003, t. XXIX, cz. 1, s. 291-292. 
praktyki działania władz ZHP różnych szczebli w latach siedemdziesiątych $i$ osiemdziesiatych ${ }^{25}$. Ważne, by mieć na uwadze funkcjonowanie skautingu i harcerstwa w określonych warunkach społeczno-politycznych i ekonomicznych, kulturalnych, jak również sytuacji międzynarodowej. Nie wolno pomijać także głównych nurtów myśli wychowawczej, doktryn pedagogicznych dominujących w danym okresie działalności harcerstwa. Historyk dziejów harcerstwa Adam Kiewicz pisze: Harcerstwo od chwili swego powstania nie działało $w$ próżni politycznej i nie było monolitem pod tym względem. $\mathrm{Na}$ jego terenie ścierały się różne orientacje, o wpływy w organizacji zabiegały różne ugrupowania polityczne. Odbijat się $w$ nim, niczym $w$ zwierciadle, układ sit politycznych w kraju. [Jego zdaniem] W nowe stulcie swej działalności ruch harcerski wchodzi rozczłonkowany organizacyjnie, z wieloma doświadczeniami programowymi i organizacyjnymi, z cała gama stuletniego dorobku przynoszacego uznanie $i$ zastużony autorytet wychowawczy, ale też z doświadczeniami, które życie odrzuciło ${ }^{26}$. Jest to niewątpliwie klucz do zrozumienia i rozpatrywania problematyki patriotyzmu w organizacji harcerskiej, w szczególności w ZHR.

Na konieczność historycznego ujmowania harcerstwa zwracał już uwagę Tadeusz Strumiłło, który pisał, że aby zrozumieć $i$ docenić swoiste cechy $i$ znaczenie polskiego Harcerstwa, trzeba na nie spojrzeć historycznie i uprzytomnić sobie jego geneze na tle ciagłości życia młodzieży polskiej w okresie niewoli ${ }^{27}$.

Spory i dyskusje ideowe na temat modelu i kierunku wychowania harcerskiego toczyły się wśród kadry instruktorskiej już od początków ruchu skautowego na ziemiach polskich. Niektórzy uważają, że w tych sporach i dyskusjach ścierały się co najmniej dwa nurty. Pierwszy z nich wskazywał na konieczność prowadzenia wychowania harcerskiego na zasadach religii Kościoła rzymskokatolickiego. Drugi nurt kładł w zasadzie nacisk na znaczenie wychowania wojskowego w harcerstwie ${ }^{28}$. Już Stanisław Sedlaczek w referacie wygłoszonym na Konferencji Starszyzny podjął bardzo ważny w kontekście wychowania harcerskiego problem stosunku w ruchu skautowym do wychowania religijnego oraz postulatów Kościoła w zakresie wychowania harcerskiego młodzieży katolickiej. Wskazał także na potrzebę określenia wartości systemu harcerskiego dla wychowania religijnego ${ }^{29}$. Znajduje to wyraz w podstawowych założeniach ideowo-wychowawczych

25 Ibidem, s. 47.

26 A. Kiewicz, Zaduma nad stuleciem, „Rocznik Historii Harcerstwa” 2010 nr 6, Warszawa 2010, s. 13, 34.

27 T. Strumiłło, Nasze dzieje. Numeracja „Harcerskich Zeszytów Historycznych” jest podwójna. Pierwszy numer oznacza kolejność ukazania się Zeszytu, drugi numer oznacza kolejność chronologiczną rozdziału w zbiorze wszystkich Zeszytów, które stanowią zawartość tomu. Redakcja wskazuje, że każdy Zeszyt stanowi tematycznie zamkniętą całość.

${ }^{28}$ Zob. K. Eychler, Harcerstwo Polskie (,Hufce Polskie”) 1939-1944. Geneza, założenia ideowe i programowe, wychowanie religijne, „Chrześcijanin w świecie” 1988 nr 173, s. 51. Zob. także J. Kwiek, Życie religijne $w$ harcerstwie 1945-1950, s. 60-77.

${ }_{29}$ S. Sedlaczek, Harcerstwo a wychowanie religijne, „Chrześcijanin w świecie” 1988 nr 173, s. 89-92. Referat jest przedrukiem z: O wychowanie $i$ życie religijne w harcerstwie, Warszawa 1931, s. 3-10. W referacie przedstawiono stanowisko skautingu angielskiego w ujęcia Baden-Powella w kwestii religii. 
i statutowych ZHR oraz przyjętym i realizowanych formach i metodach działalności wychowawczej.

Andrzej Małkowski uważany za inicjatora i twórcę polskiego skautingu ${ }^{30}$, którego działalność i jego małżonki Olgi na stałe pozostawiła po sobie ślady w historii polskiego skautingu oraz polskiej myśli w praktyce edukacyjnej XX wieku ${ }^{31}$ w wydanej w $1911 \mathrm{r}$. publikacji pisał: w szczególności nauka scoutingu wymaga rozwinięcia następujacych przymiotów i zapoznania się z następujacymi wiadomościami: [...] Partjotyzm. Geografja Polski. Historja polska i życiorysy naszych wielkich ludzi. Obowiazki dobrych obywateli. Stużba Sprawie. /Stużba sokolaß². Także w pierwszej publikacji, mającej na celu zastosowanie zasad skautingu w stosunku do dziewcząt czytamy, że: Polskie skautki w swej pracy różnia się od skautów, jakkolwiek maja z nimi dużo wspólnego. To, co czyni je podobnymi do skautów, jest chęć stużenia sprawie narodowej przyzwyczajenie się do dawania sobie rady w każdym położeniu. Ta droga będa skautki kształcity swoje charaktery, wychowując się na dobre obywatelki Polski33. Prace i ćwiczenia, a także egzaminy skautowe obowiązujące dziewczęta - kandydatki na skautki obejmowały między innymi zagadnienia dotyczące patriotyzmu, których zakres sformułowano w brzmieniu: Partyjotyzm - Życie religijne. Karność. Obowiązkowość. Wytrwałość. Ofiarność. Dobre obyczaje. Znajomość historji i gieografii Polski. Poznanie przemystu domowego. Posłannictwo kobiety polskiej ${ }^{34}$. Obowiązki te sformułowano na bazie wytycznych Baden-Powella, który uważał, że: Celem wychowania skautowego jest podniesienie poziomu przyszłych, wzorowych obywateli [...], Obywatelskość określić można krótko jako ,czynna wierność dla społeczeństwa”. W wolnym kraju najczęściej uważa sie już za dobrego obywatela każdego kto stucha praw, robi swoje i wyraża własne zdanie o polityce, sporcie lub o czyimś zachowaniu, zostawiając innym troskę o pomyślność narodu. To jest obywatelskość bierna. Ale bierna obywatelskość to nie dosyć, by wprowadzić w życie zasady wolności, sprawiedliwości $i$ honoru. Tego może dokonać tylko czynna postawa ${ }^{35}$. Kwestię relacji Bóg - Ojczyzna, miłości do Ojczyzny i służby Ojczyźnie, Baden-Powell ujął między

30 Zob. E. Głowacka-Sobiech, Twórcy polskiego skautingu - Olga i Andrzej Małkowscy, Poznań 2003, S. 8 .

31 E. Głowacka-Sobiech, W rocznicę śmierci Olgi i Andrzeja Małkowskich - twórców polskiego skautingu, „Biuletyn Historii Wychowania” 2004 Nr1/2 (19/20), s. 40. E. Głowacka-Sobiech, która w cytowanej monografii przedstawiła losy życiowe i spuściznę Olgi i Andrzeja Małkowskich, pisze, że Ich dorobek nadal pozostaje aktualny $i$ wartościowy, bowiem kreśli ponadczasowy ideał wychowania [...] budowany i mieszczacy się w ramach nie tylko ogólnie rozumianego wychowania skautowego. Ibidem.

32 Scouting jako system wychowania młodzieży na podstawie Gienerała Baden-Powella przedstawił Andrzej Małkowski, członek grona założycielskiego Sokoła-Macierzy, Lwów 1911, w: A. Małkowski, O. Małkowska, Archiwalia. Wybór tekstów, red. B. Śliwerski, Kraków 1988.

33 Polskie skautki. Zarys organizacyjny, Lwów 1913, s. 71, w: A. Małkowski, O. Małkowska, Archiwalia. Wybór tekstów, red. B. Śliwerski, Kraków 1988. Jak podaje E. Głowacka-Sobiech do opracowania Polskich skautek poproszono Olgę Drahonowską. Andrzej Małkowski, Kazimierz Wyrzykowski i Halina Paliwodzianka zostali współredaktorami opracowania. E. Głowacka-Sobiech, W dziewięćdziesiąta rocznicę narodzin skautingu na ziemiach polskich, „Biuletyn Historii Wychowania” 2001 nr 1-2 (13-14), s. 46.

${ }^{34}$ Ibidem.

${ }^{35}$ Wskazówki dla skautmistrzów. Podręcznik teorii wychowania skautowego dla drużynowych przez lorda Baden-Powella of Gilwell twórcy ruchu skautowego, Warszawa 2010, s. 29-30. 
innymi w następujący sposób: Obok czci dla Boga i szacunku dla bliźniego, istotna rzecza jest miłość Ojczyzny. Miłość Ojczyzny ma ogromne znaczenie dla zachowania w równowadze i w odpowiedniej perspektywie pogladów człowieka. Oznaki zewnętrzne tej mitości, takie jak: salutowanie sztandaru, stawanie na baczność na dźwięk Hymnu Narodowego itp. pomagaja w jej rozwoju. Istota jednak miłości Ojczyzny jest rozwój ducha obywateli, który jest podłożem takich przejawów zewnętrznych [...] stużba dla innych i poświęcenie siebie świadczy również o gotowości stużby dla swej Ojczyzny, $w$ razie konieczności jej obrony przed obca przemoca, co jest obowiazkiem każdego obywatela. Nie znaczy to wcale, że trzeba rozwijać w chłopcu ducha krwiożerczości czy napastliwości, ani że należy wychowywać go $w$ duchu wojennym $i$ w ideale walki. Można to pozostawić do czasu, gdy nieszczęście zdarzy, że podczas wojny będzie musiat wal$c z y c^{36} \cdot$

Rozważając o genezie skautingu jako systemu wychowawczego, nie należy pomijać faktu, że polski skauting, polskie harcerstwo różniło się od skautingu angielskiego. Aleksander Kamiński, różnice między harcerstwem a skautingiem ujął następująco: Skauting angielski jest pod wybitna przewaga zabawy. Nasze harcerstwo pragnie, za pomoca dobrze zorganizowanej zabawy, starannie przygotować młodzież do odegrania roli $w \dot{z y c i u}$ społecznym ${ }^{37}$. W warunkach polskich, w latach początków skautingu ruch ten był częścią ruchu niepodległościowego. W ramach skautingu kształtowano postawy niepodległościowe młodzieży patriotycznej ${ }^{38}$. Skauting siłą rzeczy, przybierał cechy ruchu paramilitarnego. Stał się istotnym elementem walki o niepodległośćc ${ }^{39}$. Sytuacja na ziemiach polskich pod zaborem pruskim, lata I wojny światowej i walki o niepodległość odrodzonego w 1918 r. państwa polskiego, okres okupacji 1939-1945, a także okres stalinizmu w Polsce wpływały na paramilitarny i niepodległościowo-patriotyczny charakter polskiego skautingu i harcerstwa, w tym jego system wychowawczy, a co za tym idzie wychowanie patriotyczne ${ }^{40}$. Fakt ten jest czynnikiem determinującym odmienność skautingu i harcerstwa polskiego. Byt źródłem jego odmienności zarówno w zakresie wychowania patriotycznego, jak i paramilitarnego.

System wychowania w skautingu, harcerstwo jako system wychowania podlegało przemianom i ciągłemu rozwojowi w zmieniających się warunkach społeczno-politycznych, ekonomicznych. Proces ten trwa w obecnym społeczeństwie współczesnym, postnowoczesnym, postindustrialnym.

\footnotetext{
36 Ibidem, s. 67.
}

${ }^{37}$ A. Kamiński, Kragg Rady, Katowice 1935, s.15. Za: J.J. Czarkowski, O metodzie harcerskiej i jej rozwoju, w: Na tropach harcerskiej metodyki. 100 lat harcerstwa polskiego, pod red. G. Miłkowskiej, K. Stech, Zielona Góra 2011, s. 16.

${ }^{38}$ Zob. J. Karwat, Od idei do czynu, Myśl i organizacje niepodległościowe w Poznańskiem w latach 1887-1919, Poznań 2002, s. 230-248, 296-300.

39 Ibidem, s. 230-248.

${ }^{40}$ W stużbie Bogu, Ojczyźnie i bliźnim. O skautingu i harcerstwie z Wojciechem Hausnerem rozmawia Barbara Polak, „Biuletyn Instytutu Pamięci Narodowej”, 2010 nr 5-6 (114-115), s. 4. Według W. Hausnera najkrótszą definicję harcerstwa sformułował Stanisław Broniewski, który mówił, że harcerstwo to jest skauting plus niepodległość (s. 4). 
Harcerstwo - fenomenalny społeczny ruch społeczny mający swój rodowód w skautingu angielskim stał się rdzennie polską organizacją. Miało to określone implikacji w dziedzinie wychowania patriotycznego. Badacz dziejów harcerstwa Adam Kiewicz, wskazując na wielką rolę w powstaniu i rozwoju skautingu na ziemiach polskich oraz kształtowaniu jego oblicza przez organizacje polskiej młodzieży o charakterze niepodległościowym proces ten ocenia następująco: Tak więc już od początku swojej drogi skauting polski odchodził daleko i znacznie od angielskiego pierwowzoru. Wyrastat na gruncie polskich realiów politycznych, umiejętnie wykorzystywat tradycje narodowa w nazwie, stroju, symbolice, odpowiadat dążeniom i aspiracjom ówczesnego pokolenia polskich dziewcząt i chłopców ${ }^{41}$.

Wychowanie patriotyczne w harcerstwie należy analizować na tle społeczno-politycznego, ekonomicznego i kulturalno-intelektualnego życia społeczeństwa i państwa polskiego, jak również stanu, tendencji, nurtów i koncepcji nauk o wychowaniu. Tomasz Strzembosz (1930-2004), przewodniczący ZHR w latach 1989-1992, swoje rozważania na temat harcerstwa polskiego konkluduje: Idea, powstała w latach 1910-1912, przetrwała przez nastepne osiemdziesiąt lat pomimo wielu trudności: pozostała $w$ społeczeństwie polskim epoki totalitarnego zniewolenia i odnalazła się w skomplikowanym świecie III Rzeczypospolitej. Harcerstwo nie zdradziło Polski niepodległej, było jej wierne ${ }^{42}$.

W rozważaniach nad problematyką wychowania w organizacji harcerskiej zasadne jest poszukiwanie i wskazywanie tych elementów, które są pomocne w zrozumieniu jej tradycji, historycznych uwarunkowań, współczesnego kształtu, systemu aksjologiczne$\mathrm{go}^{43}$. Uwaga ta powinna mieć zastosowanie także w refleksji nad harcerską metodą wychowawczą ZHR w kontekście tradycji, na które powołuje się związek. Związek Harcerstwa Rzeczypospolitej - czytamy w uchwale założycielskiej stowarzyszenia - jest spadkobierca tradycji ideowej polskiego harcerstwa od jego zarania, kontynuatorem zasad programowych, metodycznych i organizacyjnych istniejacego w latach 1918-1939 Zwiazku Harcerstwa Polskiego; pragnie twórczo rozwijać dorobek niezależnych środowisk harcerskich po 1945 roku ZHP i poza nim ${ }^{44}$.

Harcerstwo polskie zapoczątkował ruch skautowy zdefiniowany jako dobrowolny, apolityczny ruch wychowawczy dla młodzieży, otwarty dla wszystkich bez względu na pochodzenie, rase czy wyznanie, zgodny z celem, zasadami i metoda, które ustalit zało$\dot{z y c i e l}$ [Robert Baden-Powell] ${ }^{45}$. Celem ruchu skautowego jest przyczynianie się do roz-

${ }^{41}$ A. Kiewicz, Zaduma nad stuleciem, „Rocznik Historii Harcerstwa” 2010 nr 6, Warszawa 2010, s. 12.

${ }^{42}$ T. Strzembosz, Refleksje o harcerstwie $i$ wychowaniu, Warszawa Poznań 2006, s. 198. Cytowany tekst opublikowano wcześniej w czasopiśmie „Ethos” 2000 nr 3 (51), s. 87-199. Według T. Strzembosza najkrótsza definicja harcerstwa brzmi: jest to rycerski ksztalt chrześcijaństwa. Ibidem.

${ }^{43}$ B. Jakubowska, Najnowsza historia wychowania - ttem dla dziejów harcerstwa, w: Ideaty wychowawcze i myśl polityczna harcerstwa polskiego. Materiały z konferencji naukowej zorganizowanej z okazji 100-lecia harcerstwa w Polsce, pod red. G. Baziura, Oświęcim 2011, s. 9.

${ }^{4}$ Vademecum Jubileuszowego Zlotu Stulecia Harcerstwa, Kraków - Łagiewniki 25-28 VII 2011 r., s. 83.

45 Elementy programu skautowego, tłum. Andrzej Horoszkiewicz, Anna Węgrzyn, red. Krystyna Regulska, Warszawa 1991, s. 18. Publikacja stanowi efekt pracy różnych zespołów powołanych przez Światową Organizację Ruchu Skautowego (WOSM). Objaśnienie pojęcia i zasad ruchu s. 18-20. 
woju młodych ludzi w taki sposób, by w pełni mogli wykorzystać swoje możliwości fizyczne, umysłowe, społeczne i duchowe jako jednostki oraz odpowiedzialni obywatele i jako członkowie wspólnot lokalnych, narodowych i międzynarodowych ${ }^{46}$.

Podstawowymi zasadami ruchu skautowego są wierzenia i prawa stanowiące kodeks postępowania wyróżniający wszystkich uczestników ruchu. Uczestnicy ruchu są obowiązani w dążeniu do celu ruchu skautowego przestrzegać obowiązujące wierzenia i prawa skautowe ${ }^{47}$. Pierwsza z zasad ruchu skautowego Obowiazek wobec Boga jest zdefiniowana jako wierność zasadom duchowym, lojalność wobec religii, która je wyraża i akceptacja obowiązów, które z niej wynikaja ${ }^{48}$. Zasada Obowiązki wobec bliźnich określona jest jako Lojalność wobec własnego kraju połaczona z popieraniem lokalnego, narodowego i międzynarodowego pokoju, porozumienia $i$ wspótpracy, udział $w$ rozwoju społeczeństwa połaczony z uznaniem i poszanowaniem godności drugiego człowieka oraz nienaruszalności świata przyrody ${ }^{49}$. Należy zwrócić uwagę, co jest istotne w kontekście rozważań o patriotyzmie, że idea lojalności wobec własnego państwa jest traktowana w szerszej perspektywie. Idea ta musi pozostawać w zgodzie z popieraniem pokoju porozumienia i współpracy na szczeblu lokalnym, narodowym i międzynarodowym. Stwierdzenie udział $w$ rozwoju społeczeństwa wyraża kompleksowo zasadę służby bliźnim w znaczeniu przyczyniania się do rozwoju społeczności na zasadzie poszanowania godności człowieka i przyrody. Zasada Obowiąek wobec samego siebie oznacza odpowiedzialność za własny rozwój, rozwój swojej osobowości, w których to podstawową rolę odgrywają Przyrzeczenie i Prawo skautowe. Zasada Wierność Przyrzeczeniu i Prawu sprowadza się zasadniczo do obowiązku posiadania własnego Przyrzeczenia i Prawa przez wszystkie stowarzyszenia skautowe. Przyrzeczenie i Prawo powinny być jednak sformułowane w zgodzie z założeniami ruchu skautowego. Są zatwierdzane przez WOSM $^{50}$.

Koncepcja wychowania przez działanie jest podstawą podejścia do rozwoju społecznego, który powinien mieć charakter progresywny i odbywać się poprzez zdobywanie przez skautów własnych doświadczeń w warunkach przyjaźni i braterstwa wszystkich ludzi ${ }^{51}$.

46 Ibidem, s. 20. Identycznie cel ruchu skautowego określono w statucie Światowej Organizacji Ruchu Skautowego (WOSM). Ibidem, s. 41. W Elementach programu skautowego podkreśla się, że skauting jest jednym z czynników wpływających na rozwój młodych ludzi i jako ruch nie zamierza zastępować rodziny, jak również instytucji religijnych, społecznych. Skauting jest pomyślany jako uzupetnienie wychowawczego oddziaływania tych czynników. s. 20. Pojmowanie odpowiedzialnego obywatelstwa, które stanowi jeden z podstawowych celów skautingu jest szerokie. Wskazuje się, że każda osoba jest jednostką swojego najbliższego otoczenia wchodzącego w skład szerszej struktury politycznej danego państwa, które jest z kolei elementem wspólnoty międzynarodowej. Odpowiedzialny obywatel musi być świadomy swych praw i obowiązków w stosunku do społeczności, do których należy (s. 20-21).

47 Ibidem, s. 21.

48 Ibidem.

49 Ibidem, s. 22.

50 Ibidem, s. 22-24.

51 Ibidem, s. 43-44. 
Natomiast idea rozwoju duchowego przesądza o kierunku poszukiwań programowych metod skautingu, które powinny odpowiadać zdolnościom i ograniczeniom różnych grup wiekowych młodzieży skautowej52.

Metodą skautową nazywa się zestaw stosowanych środków lub podejmowanych dziatań dla osiagnięcia celu. Ilekroć metoda ta jest częścią ruchu, głoszacego pewne zasady, jak to jest $w$ przypadku skautingu, tylekroć musi się ona opierać na tych samych zasadach. Metoda skautowa bywa określana jako ,system stale doskonalonego samowychowania poprzez: Przyrzeczenie i prawo, Wychowanie przez działanie, Przynależność do matych grup [...], Stale doskonalone stymulujace programy różnorodnych zajęć oparte o zainteresowania uczestników, zawierające gry, kształcenie umiejętności praktycznych i pracę dla spoleczeństwa; większość tych zajęć odbywa się na wolnym powietrzu $i$ w kontakcie z przyroda ${ }^{53}$. Za jeden z najważniejszych aspektów metody skautowej uważa się jej stale doskonalony charakter we wszystkich dziedzinach działalności ruchu. Cecha stałego doskonalenia metody skautowej polega na uczeniu się stopniowego brania przez skautów na siebie odpowiedzialności, przynależności do małych grup o rozmiarach przystosowanych do potrzeb danej grupy wiekowej, uczestnictwie w podejmowaniu decyzji w formie odpowiadającej grupie wiekowej planie rozwoju (systemie sprawności i odznak), ćwiczeniu umiejętności przywódczych, poszerzaniu horyzontów w miarę dorastania skautów ${ }^{54}$.

Najważniejszym środkiem prowadzącym do osiągania celu skautingu jest program. Zaleca się by programy w organizacjach skautowych były opracowywane na zasadzie systemowego podejścia do rozwoju programowego. Proponowana forma modelu dla rozwoju programowego opiera się na kilku założeniach. Po pierwsze, skauting - mając na uwadze jego cele - należy widzieć jako instytucję kształcącą. Po drugie, każdy proces wychowawczy w ruchu skautowym zarówno sformalizowany, jak i niesformalizowany powinien mieć na celu wywoływanie zmian w wiedzy i osobowości skautów w kierunku takim, aby cel ruchu został osiągnięty. Po trzecie, skauting jako ruch wychowawczy powinien uwzględniać wyniki prac naukowych, których przedmiotem jest wychowanie. Powyższe powinno umożliwić wyróżnienie trzech ważnych idei mogących znaleźć zastosowanie w programach skautowych. Pierwsza idea zakłada rozumienie rozwoju programowego skautingu jako serię działań i przedsięwzięć, które tworzą cykl działań o charakterze ciągłym. Według drugiej idei, celem rozwoju programowego jest wywołanie zmian w ruchu skautowym. Warunkiem nastąpienia tych zmian są skutecznie przeprowadzone zmiany programowe. W myśl idei trzeciej, wszelka zmiana w ruchu skautowym będzie tym bardziej skuteczna, jeżeli wprowadzać ją będą ludzie ściśle zaangażowani w rozwój programowy ${ }^{55}$.

Metoda harcerska w harcerstwie polskim została formalnie umocowana w statutach ZHP w okresie międzywojennym z 1923 r. i 1936 r. ${ }^{56}$ W statucie ZHR uchwalonym przez

\footnotetext{
52 Ibidem, s. 35.

53 Ibidem, s. 24-25.

54 Patrz: przedstawienie cech metody skautowej, ibidem, s. 61-79.

55 Ibidem, s. 81-82. Patrz: przedstawienie istoty systemowego podejścia do programu, ibidem, s. 80-101.

56 S. Czopowicz, Bogu Polsce bliźnim. Obraz harcerstwa Rzeczypospolitej Niepodległej, spuścizna ideowa $i$ wychowawcza, Warszawa 2004, s. 150-151.
} 
I Walny Zjazd, który odbył się w dniach 1-2 kwietnia 1989 r. w $\$ 4$ pkt 2 rozdziału II: Charakter, cele $i$ środki działania wprowadzono zapis: Zwiazek pracuje metoda harcer$s k a^{57}$. Metoda harcerska w ZHR została szeroko przedstawiona i zinterpretowana w Podstawowych zasadach wychowania harcerskiego $w Z H R^{58}$. Analizę ujęcia i interpretacji metody harcerskiej w Podstawowych zasadach... zasadnym jest dokonywać z uwzględnieniem podstaw ideowych wychowania harcerskiego i celów wychowania ZHR. W dokumencie czytamy, że ZHR na płaszczyźnie ideowej i programowej jest kontynuatorem myśli wychowawczej wielu pokoleń harcerek $i$ harcerzy. Kontynuacja ta opiera się nie tylko na przyjęciu tradycji i spuścizny intelektualnej, ale także na czynnym zaangażowaniu harcerek i harcerzy. W dalszej części Podstawowych zasad stwierdza się, że: Harcerski ideat wychowawczy zostat przedstawiony w postaci Prawa Harcerskiego. Źródłem tworzacych go wartości jest Dekalog. A treść 10 punktów Prawa stanowi rozwinięcie Przykazań Bożych, w tym najważniejszego - przykazania Miłości. Tekst Prawa i Przyrzeczenia harcerskiego stosowany w ZHR pochodzi z roku 1936. W części dotyczącej podstaw ideowych wychowania harcerskiego Podstawowych zasad... podkreśla się historyczny proces kształtowania się rozumienia treści zawartych w Prawie Harcerskim, droge prowadzaca do Prawdy, Dobra i Piękna, poprzez umiłowanie Boga, Polski i bliźnich. Harcerska idea i metoda wychowawcza w sposób szczególny znajduja odzwierciedlenie w Przyrzeczeniu Harcerskim. W myśl Podstawowych zasad... w gromadach zuchowych wychowanie jest prowadzone na podstawie Prawa Zucha, które stanowi dostosowaną do zuchów wykładnię praw i ideałów, na których opiera się Prawo Harcerskie. Na wyrażonej przez każdego członka ZHR woli służby Bogu, Polsce i bliźnim opierają się podstawy ideowe harcerskiego systemu wychowawczego. Służba Polsce oznacza powinności patriotyczne $i$ obywatelskie. Mając na uwadze teorie pedagogiczne w Podstawowych zasadach..., stwierdza się, że personalizm chrześcijański, który bierze pod uwage odrębność i jedyność osoby ludzkiej jest podstawą wychowania harcerskiego. Wskazuje się, że w wymiarze pedagogicznym personalizm chrześcijański służy samodoskonaleniu człowieka w wymiarze duchowym, emocjonalnym, intelektualnym, fizycznym i społecznym ${ }^{59}$. W części Podstawowych zasad... zatytułowanej Cele wychowania ZHR czytamy, że: Harcerstwo ma na celu wychowanie metoda harcerska - w myśl Przyrzeczenia i Prawa harcerskiego dzielnych, prawych i zdolnych do poświęceń ludzi. Wychowanie harcerskie ma na celu przede wszystkim stwarzanie warunków harmonijnego i petnego rozwoju człowieka we wszystkich obszarach jego osobowości. Dalej stwierdza się: Cecha wychowania harcerskiego jest szczególnie uwrażliwienie młodego pokolenia na przyjmowanie postaw i realizację działań najbardziej potrzebnych współczesnej Polsce, w tym w szczególności: Kształtowanie zmystu obywatelskiego i cnót spolecznych:

${ }^{57}$ Statut ZHR uchwalony przez I Walny Zjazd w dniach 1-2 kwietnia 1989 r. [...] http://stare.zhr.pl/naczelnictwo/statut.php dostęp: 30.04.2011.

${ }^{58}$ Podstawowe zasady wychowania harcerskiego w ZHR (Dokument zatwierdzony uchwała Rady Naczelnej ZHR nr 77/4 z 26 listopada 2005 r., uwzględniajacy zmianę wprowadzona uchwała Rady Naczelnej ZHR nr 83/4 z 10 grudnia 2006 r.), Naczelnictwo Związku Harcerstwa Rzeczypospolitej.

59 Ibidem, s. 3,4. 
odpowiedzialności za swoje czyny i za wspólnotę, aktywności społecznej, pracowitości, rzetelności, odwagi i poświęcenia [...] Wychowanie $w$ duchu umiłowania ojczyzny i szacunku do jej historii [...] naukę postaw patriotycznych we współczesnej rzeczywistości, rozumienie $i$ wspóltworzenie dorobku narodowego, pielegnowanie i pomnażanie dorobku kultury $i$ tradycji narodowej, idace $w$ parze z otwarciem na rzeczywiste wartości płynace z Europy $i$ świata oraz problemy innych narodów. Stużbę wobec wspólnot i społeczeństwa rozumiana jako stużba Bogu i stużba Polsce ${ }^{60}$. Cześć trzecia Podstawowych zasad... ma tytuł Metoda harcerska. Zdefiniowano w niej metodę harcerską następująco: Metoda harcerska jest prostym, spójnym $i$ konkretnym sposobem praktycznej realizacji harcerskiego wychowania. W ujęciu dokumentu metoda harcerska określa sposób zmierzania do celów harcerskiej pracy. Wskazuje się, że zasady działania instruktorów i całej organizacji harcerskiej są wyznaczone przez metodę harcerską, której fundamentem są konsekwentnie wynikajace z siebie $i$ wzajemnie powiązane elementy. Podkreśla się, że poszczególne zasady i podstawowe środki metody harcerskiej stanowia jedność, której nie można dzielić na mniejsze części. Brak możliwości podziału metody harcerskiej lub rezygnacji z którejkolwiek jej części ma uniemożliwić ryzyko zaprzeczenia celowości harcerskiej pracy. Metoda harcerska, mająca swą genezę u początków skautingu i harcerstwa polskiego oraz doświadczenia w jej stosowaniu wskazują, iż stanowi ona system skuteczny $i$ uniwersalny. Metoda harcerska posiada kardynalne zasady. Pierwsza z nich to zasada neutralności. Jej rozwinięciem jest druga kardynalna zasada metody harcerskiej zwana zasada oddziaływania od wewnątrz. Zasadą warunkująca skuteczne wypełnienie dwóch pierwszych zasad jest zasada trzecia: Zasada dobrowolności. Jej istotą jest świadomy stosunek do harcerstwa zuchenek, zuchów, harcerek i harcerzy, instruktorek i instruktorów. Do kolejnych kardynalnych zasad metody harcerskiej należą zasady: oddziaływania pośredniego, oddziaływania pozytywnego, wzajemności oddziaływań. Podstawowymi środkami realizacji metody harcerskiej w ZHR są: system zastepowy, wzorzec osobowy instruktora, stopniowanie trudności, wychowanie w oparciu o przyrodę. Warunki dodatkowe skuteczności metody harcerskiej stanowią: partnerstwo instruktorów i rodziców, pełnienie wszystkich funkcji w związku społecznie oraz równoległe działanie męskiego i żeńskiego pionu wychowawczego w organizacji. Zgodnie $\mathrm{z}$ harcerską metodą wychowawczą wychowanie w ZHR prowadzone jest w poszczególnych grupach wiekowych: zuchów (7-10 lat), harcerek i harcerzy (11-14 lat), wędrowniczki i wędrownicy (15-17 lat), harcerski starsze i harcerze starsi tworzący kręgi harcerstwa starszego, w których może występować koedukacja ${ }^{61}$.

Metoda harcerska jest przedmiotem naukowego opisu w literaturze pedagogicznej. Szczególną dorobek w tym zakresie ma Aleksander Kamiński, który jest autorem szczególnej pracy na temat metody harcerskiej ${ }^{62}$. Nie sposób oczywiście pominąć klasycznego opracowania poświęconego metodzie harcerskiej autorstwa Ewy Grodeckiej uwzględnia-

\footnotetext{
60 Ibidem, s. 5.

${ }^{61}$ Ibidem, s. 6-8.

${ }^{62}$ A. Kamiński, Nauczanie $i$ wychowanie metoda harcerska, Warszawa 1948. Praca była kilkakrotnie wznawiana.
} 
jącej dorobek kursów podharcmistrzyń (I-XXIII), które odbyły w Harcerskiej Szkole Instruktorskiej na Buczu w latach 1933-1936, napisanej w okresie dwudziestolecia międzywojennego i mającej swoje kolejne wydania ${ }^{63}$. Wiele innych polskich opracowań zwartych, artykułów w czasopismach i publikacji mających charakter poradników bazuje W znaczącej części na pracach twórcy skautingu angielskiego, a przede wszystkim naukowym dorobku pedagogicznym Aleksandra Kamińskiego i na opracowaniu Ewy Grodeckiej.

Zachowanie zgodności z zasadami i praktyką poznawania naukowego wskazuje na potrzebę badań naukowych, poszukiwań odpowiedzi na pytanie o zakres i stopień uwzględniania w wychowaniu patriotycznym w ZHR kontekstu społecznego, politycznego, ekonomicznego, kulturalnego, jak również indywidualnego dla rozwoju harcerzy, percepcji patriotyzmu w środowisku harcerskim ${ }^{64}$, skuteczności tego wychowania w odniesieniu do założeń ideowo-wychowawczych i celów harcerskiego wychowania.

$\mathrm{Z}$ uwagi na przedmiot rozważań w niniejszym tekście i próbę nadania tym rozważaniom charakteru historyczno-pedagogicznego oraz odwołanie się do ujęcia problemu patriotyzmu w perspektywie historycznej przez Marcina Kulę w początkowej części tekstu warto przytoczyć uwagi stanowiące pewną konkluzję rozważań o patriotyzmie w dobie współczesnej. M. Kula podkreśla konieczność spełnienia określonych postulatów warunkujących zaistnienie sytuacji takiej, w której warto będzie mówić o wychowaniu patriotycznym. Tyle, że wtedy nie będzie już chyba potrzeby takiej rozmowy. [...] Bowiem rozumny patriotyzm będzie czymś spontanicznie naturalnym, wtedy też nieustajace oddawanie hołdu cieniom bohaterów uda się, być może, zastapić nie mniej potrzebna dyskusja nad losami i drogami ewolucji narodu, co nie jest sprzeczne ani z patriotyzmem, ani z szacunkiem dla zmarlych za ojczyznę. Oddanie hołdu powstańcom nie wyklucza pytania o sens powstań narodowych lub (i) refleksji nad docenianiem (badź niedocenianiem) w trakcie biegu dziejów potrzeby cywilizacyjnego rozwoju kraju ${ }^{65}$.

Niniejszy artykuł nie stanowi próby wyczerpania ważnego i złożonego problemu problematyki patriotyzmu w organizacji harcerskiej w odniesieniu do ZHR. Jest pewną próbą zarysowania jej podstawowych zrębów, elementów i treści. Można przyjąć, że tekst dotyczy przeglądu najistotniejszych kwestii przedmiotu rozważań, naturalnie w określonym zakresie w ramach dyskursywnej walki dotyczącej wychowania młodych obywateli we współczesnym społeczeństwie polskim w procesie zmiany systemowej ${ }^{66}$.

${ }^{63}$ E. Grodecka, O metodzie harcerskiej i jej stosowaniu, Warszawa 1998.

${ }^{64}$ Zob. np. A. Przecławska, Bóg, honor i ojczyzna w recepcji współczesnej młodzieży - refleksje pedagoga, w: Wychowanie. Pojęcia - Procesy - Konteksty, t. IV, red. nauk. M. Dudzikowa, M. Czerepaniak-Walczak, Gdańsk 2008, s. 73-94.

${ }^{65}$ M. Kula, Nieznośny ciężar kompleksów, s. 35. Autor uważa, że rozumny patriotyzm będący czymś spontanicznie naturalnym zaistnieje w następujących warunkach społeczno-ekonomicznych i politycznych: Posiłek dla wszystkich głodnych dzieci, sensowna szkoła, niezłe nauczanie historii, polskiego oraz wiadomości o Polsce, ułatwienie młodzieży poznania własnego kraju, praca dla rodziców, zaistnienie w Polsce takiego stylu uprawiania polityki, który nie odrzucat by na kilometr... ibidem, s. 35.

${ }^{66}$ Z. Melosik, Wychowanie obywatelskie: nowoczesność, ponowoczesność (próba konfrontacji), w: Wychowanie obywatelskie. Studium teoretyczne, porównawcze i empiryczne, pr. zbior. pod red. Z. Melosika i K. Przyszczypkowskiego, Poznań-Toruń 1998. 